\title{
ESP v1.0: methodology for exploring emission impacts of future scenarios in the United States
}

\author{
D. H. Loughlin ${ }^{1}$, W. G. Benjey ${ }^{2}$, and C. G. Nolte ${ }^{2}$ \\ ${ }^{1}$ US Environmental Protection Agency, National Risk Management Research Laboratory, 109 T.W. Alexander Drive, \\ Research Triangle Park, NC 27711, USA \\ ${ }^{2}$ US Environmental Protection Agency, National Exposure Research Laboratory, 109 T.W. Alexander Drive, \\ Research Triangle Park, NC 27711, USA
}

Received: 23 September 2010 - Published in Geosci. Model Dev. Discuss.: 2 November 2010

Revised: 25 March 2011 - Accepted: 28 March 2011 - Published: 8 April 2011

\begin{abstract}
This article presents a methodology for creating anthropogenic emission inventories that can be used to simulate future regional air quality. The Emission Scenario Projection (ESP) methodology focuses on energy production and use, the principal sources of many air pollutants. Emission growth factors for energy system categories are calculated using the MARKAL energy system model. Growth factors for non-energy sectors are based on economic and population projections. These factors are used to grow a 2005 emissions inventory through 2050. The approach is demonstrated for two emission scenarios for the United States. Scenario 1 extends current air regulations through 2050, while Scenario 2 adds a hypothetical $\mathrm{CO}_{2}$ mitigation policy. Although both scenarios show significant reductions in air pollutant emissions through time, these reductions are more pronounced in Scenario 2, where the $\mathrm{CO}_{2}$ policy results in the adoption of technologies with lower emissions of both $\mathrm{CO}_{2}$ and traditional air pollutants. The methodology is expected to play an important role within an integrated modeling framework that supports the US EPA's investigations of linkages among emission drivers, climate and air quality.
\end{abstract}

\section{Introduction and objectives}

Anthropogenic air pollutant emissions are responsible for many current air quality problems, including photochemical smog, acid rain, and atmospheric fine particulate matter. Some of these pollutants are greenhouse gases (GHGs) or radiatively active aerosols, which contribute to climate change and its associated increasing temperatures, changes

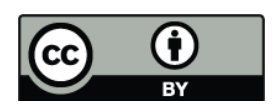

Correspondence to: D. H. Loughlin (loughlin.dan@epa.gov) in precipitation patterns, increased intensity of storm events, reduced air quality, introduction of new disease vectors, and sea-level rise (Pachauri and Reisinger, 2007; Peary et al., 2007).

Many factors will influence the sources, quantities, and locations of pollutant emissions in the future. These include population growth and migration, economic growth and transformation, depletion of energy resource supplies, climate and meteorological changes, land use and land cover changes, technology changes, future policy directions, and human behavior. To address long-term air quality and climate concerns proactively and efficiently, decision-makers need to be able to understand the linkages among these various drivers and emissions, construct scenarios that project emissions into the future, and develop, evaluate and compare candidate management strategies.

Modeling has the potential to support integrated air quality and climate decision making; however, characterizing emissions and air quality impacts decades into the future is challenging. One reason is a lack of modeling options that are directly applicable at the necessary spatial and temporal scales. The US EPA, for example, currently uses a suite of models, tools, and emission inventories in its air quality modeling (US EPA, 2010e). While these tools can simulate air quality over a range of temporal and spatial scales, they typically have been applied for a time horizon stretching only through 2020 or 2030. Many important shifts in emissions drivers are expected to occur after this horizon. Further, the bottom-up nature of the emission inventories and the computational requirements of modeling limit the number of scenarios that can be investigated.

As an alternative, integrated assessment models (IAMs) are used to investigate global climate scenarios that extend many decades or even centuries into the future. A suite of

Published by Copernicus Publications on behalf of the European Geosciences Union. 
IAMs was used within the Intergovernmental Panel on Climate Change's Special Report on Emission Scenarios (Nakicenovic et al., 2000). IAMs typically represent many aspects of global systems, including the carbon cycle, global circulation pattern and temperature changes, global and regional economics, agriculture, technology change, and pollutant emissions. Data availability and computational requirements, however, constrain IAMs to coarse spatial and temporal resolutions. Regions often consist of countries or groups of countries, time steps may be decades or more, and emissions are highly aggregated across source categories. The resulting pollutant emission estimates are not sufficiently resolved to investigate many regional air quality issues in detail.

These limitations point to the need for new approaches to support climate and air quality decision making. New approaches should support modeling time horizons that extend air quality analyses out several additional decades, provide reasonably detailed emission projections for key source categories, and address uncertainty in emission drivers by facilitating the examination of wide-ranging scenarios of the future.

The US Environmental Protection Agency (US EPA) is working to meet this need through its Global Change Air Quality Assessment (GCAQA). The ultimate goal of this effort is "to provide air quality managers with the scientific information and tools to evaluate the implications of global change on their programs" (US EPA, 2009). A central component of the GCAQA is the implementation of an integrated modeling framework that includes models characterizing global circulation patterns, regional meteorology, economic growth, land-use changes, the energy system, and air quality. Parts of this framework were demonstrated in previous work that examined climate change impacts on air quality, independent of changes in anthropogenic emissions (US EPA, 2009). The results suggest that climate change, under the modeled assumptions, can lead to a $20 \%$ increase in biogenic emissions. Further, mean and 95th percentile surfacelevel ozone concentrations are likely to increase over much of the US, and the ozone season is expected to lengthen (Nolte et al., 2008; Weaver et al., 2009; US EPA, 2009). For the next phase of the GCAQA, emissions through 2050 are being developed and the resulting air quality impacts will be evaluated.

The GCAQA is implementing a scenario-based approach to emissions development (Schwartz, 1996), in contrast to approaches in which a single, best guess emission projection is developed (e.g., Woo et al., 2008). The mechanism by which the GCAQA scenarios are translated into future emissions is a critical component of the integrated framework. The purpose of this paper is to introduce a methodology for this translation. The methodology is referred to as the Emission Scenario Projection (ESP) methodology. Version 1.0 of the methodology is described and demonstrated here. National and regional emission responses for two hypothetical scenarios are examined. Refinements to the ESP methodology are ongoing, and short- and long-term improvements are discussed at the end of the paper.

\section{General methodology}

The energy system is a major source of air pollutant emissions. In 2005, energy-related sources contributed approximately $94 \%$ of anthropogenic carbon dioxide $\left(\mathrm{CO}_{2}\right), 95 \%$ of anthropogenic nitrogen oxides $\left(\mathrm{NO}_{\mathrm{x}}\right), 92 \%$ of anthropogenic sulfur dioxide $\left(\mathrm{SO}_{2}\right)$, and $10 \%$ of anthropogenic particulate matter emissions of less than $10 \mu \mathrm{m}$ in diameter $\left(\mathrm{PM}_{10}\right)$ within the United States (US EPA, 2009b, 2010). As demands for energy are expected to increase over time, the evolution of the energy system will have implications on future air quality. Energy system models have the potential to provide important insights into these implications.

The MARKet ALlocation (MARKAL) model (Fishbone and Abilock, 1981; Loulou et al., 2004; Rafaj et al., 2005) is an energy system optimization model. MARKAL represents energy supplies and demands over a specified time horizon, as well as current and anticipated technologies for meeting those demands. MARKAL optimizes investments in technologies and fuels, apportioning market share such that energy system costs are minimized and modeled constraints are met. Model inputs can be modified to represent a particular scenario. MARKAL's response to these changes provides insights into their potential impacts on technologies, fuels, and emissions.

To analyze a particular energy system with MARKAL, a database representing that system must be developed. The US EPA has developed MARKAL databases that represent the US energy system at the national and regional levels (US EPA, 2006). The databases characterize the resource supply, electricity production, residential, commercial, industrial and transportation sectors, covering a time horizon from 2000 through 2050. Data sources include: the Department of Energy's 2006 Annual Energy Outlook (AEO06) (DOE, 2006); the US EPA's AP-42 emission factor documentation (US EPA, 1995), Greenhouse Gas Inventory (US EPA, 2009b), National Emission Inventory (NEI) (US EPA, 2010), and Integrated Planning Model (IPM) documentation (US EPA, 2010d); and Argonne National Laboratory's Greenhouse Gas, Regulated Emissions, and Energy Use in Transportation (GREET) model (Burnham et al., 2006).

The level of technological detail within the EPA MARKAL databases differs by sector, depending on data availability and importance with respect to emissions and energy use. The electricity production and light duty transportation sectors have the highest level of specificity. In 2002, these two sectors together accounted for approximately $62 \%$ of US anthropogenic $\mathrm{CO}_{2}$ emissions and $53 \%$ of anthropogenic $\mathrm{NO}_{\mathrm{x}}$ emissions. The residential and commercial sectors also have a relatively high level of detail. 
These sectors use large quantities of electricity, thus influencing emissions from the electric sector. The industrial sector is a major user of electricity and also accounts for approximately $15 \%$ of US anthropogenic $\mathrm{CO}_{2}$ emissions through direct fuel combustion. Detailed information about industrial energy use and technologies is not readily available, however, thereby limiting how that sector has been represented. The representations of heavy duty vehicle, air, shipping, and rail technologies also are currently limited. In 2002, these sectors together accounted for only $12 \%$ of transportation $\mathrm{CO}_{2}$ emissions, but $32 \%$ of transportation $\mathrm{NO}_{\mathrm{x}}$ emissions. Development of the EPA MARKAL databases is ongoing, and industrial and transportation categories are currently receiving additional attention.

Running MARKAL for a particular scenario using the national database requires only 1 to $5 \mathrm{~min}$ of computational time on a personal computer, depending on the options that are selected and computer specifications. (We currently are using a laptop with a dual-core, $2.4 \mathrm{GHz}$ processor and $3.45 \mathrm{~GB}$ of RAM.) The nine-region version, which represents the US at the Census Division resolution, requires 20 to 45 min with a similar computer configuration. A map showing the nine MARKAL regions is shown in Fig. 1. Regionalization allows consideration of fuel transportation costs and regional differences in energy supplies, demands, and technology performance. Outputs, including technologies, fuel use, and emissions, are generated at the regional level. The nine-region database was selected for the work presented here because of its ability to generate region-specific emission growth factors.

To support the GCAQA, the ESP methodology was developed. A primary component of the methodology is the approach for converting MARKAL's regional emission projections into state-level, Source Classification Code (SCC)based emission growth factors (US EPA, 2010d). These multiplicative factors can be used within the Sparse Matrix Operator Kernel Emission (SMOKE) model (Houyoux and Adelman, 2001) to grow a base-year inventory to a future year.

SCCs represent specific types of emission sources within the NEI. Emission categories are represented by 8 -to-10 digit SCC codes. The digits provide more specificity from left to right. For example, the code 10100201 represents a utility sector, wet-bottom boiler that burns bituminous coal. The leftmost digit, "1", refers to external combustion. The next two digits specify the source category, with " 01 " representing electric utilities. The following three digits represent the fuel, with "002" being bituminous or sub-bituminous coal. The last two digits specify the type of process, a wet-bottom boiler. We make use of this structure to define SCC categories that include related SCCs. For example, the category "101?????" is used to refer to all electric sector external combustion sources.

The portion of ESP methodology related to energy system emissions consists of the following steps, which are repeated

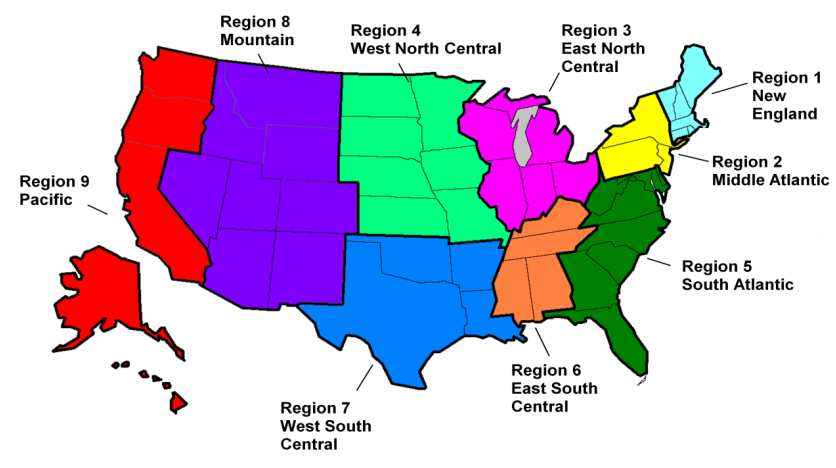

Fig. 1. The nine regions used within the US EPA MARKAL database.

for each pollutant (e.g., $\mathrm{CO}_{2}, \mathrm{NO}_{\mathrm{x}}, \mathrm{SO}_{2}$, and $\mathrm{PM}_{10}$ ) and region:

1. Emissions are summed for each MARKAL emission category and time period.

2. The summed MARKAL emissions are allocated to matching SCC categories using the crosswalk provided in Table 1. Question marks within the SCC categories are interpreted as wildcards.

3. For each SCC category, multiplicative emission growth factors are calculated by dividing the future-year value by the base-year value.

4. The resulting SCC category-, pollutant- and regionspecific growth factors are applied to all matching SCCs for each state within the region.

5. After repeating the procedure for each pollutant and region, the resulting emission growth factors are placed in a SMOKE growth and control factor file using the standard SMOKE projection packet format (CMAS, 2009).

The MARKAL database used in this study does not provide full coverage of energy sector pollutant species. To demonstrate the methodology, we made the assumption that growth factors for $\mathrm{CO}_{2}, \mathrm{PM}_{10}$ and $\mathrm{NO}_{\mathrm{x}}$ could be used as surrogates for other species. For example, energy system emissions of carbon monoxide (CO), volatile organic compounds (VOCs), and ammonia $\left(\mathrm{NH}_{3}\right)$ for most source categories are assumed to grow at the same rate as $\mathrm{CO}_{2}$. Growth factors for $\mathrm{PM}_{10}$ are applied to $\mathrm{PM}$ of $2.5 \mu \mathrm{m}$ or less $\left(\mathrm{PM}_{2.5}\right)$. For mobile sources, $\mathrm{NO}_{\mathrm{x}}$ growth factors are used for $\mathrm{CO}$, VOC and $\mathrm{NH}_{3}$ emissions. Ongoing efforts to expand pollutant coverage within the MARKAL database will reduce the need for such surrogates. For example, a more recent version of the MARKAL database now includes factors for $\mathrm{PM}_{2.5}$, $\mathrm{CO}$, and VOCs. These factors will be used in future emission scenario modeling.

Because non-combustion, industrial emissions are not modeled within MARKAL, complementary approaches 
Table 1. Crosswalk linking MARKAL emission categories with matching SCC codes. Question marks represent wildcards.

\begin{tabular}{|c|c|c|}
\hline Sector & MARKAL Category & Matching SCC codes \\
\hline Electric & $\begin{array}{l}\text { Pulverized coal boilers } \\
\text { Coal IGCC turbines } \\
\text { Biomass combustion } \\
\text { Diesel turbine, combined-cycle, } \\
\text { and Combined Heat and Power } \\
\text { Natural gas turbine, } \\
\text { combined-cycle, and CHP } \\
\text { Residual fuel oil boilers } \\
\text { Landfill gas turbines } \\
\text { Waste-to-energy }\end{array}$ & $101 ? ? ? ? ?, 201 ? ? ? ? ?, 2101 ? ? ? ? ? ?$ \\
\hline Industrial & $\begin{array}{l}\text { All except refineries } \\
\text { Refineries }\end{array}$ & $\begin{array}{l}102 ? ? ? ? ?, 202 ? ? ? ? ?, 2102 ? ? ? ? ? ?, \text { 239?????? } \\
\text { 2306????? }\end{array}$ \\
\hline Commercial & All combustion & 103?????, 105?????, 203?????, 2103?????? \\
\hline Residential & All combustion & 2104?????? \\
\hline Transportation & $\begin{array}{l}\text { Airplanes } \\
\text { Buses and heavy duty trucks } \\
\text { Light duty vehicles } \\
\text { Off-highway } \\
\text { Rail } \\
\text { Shipping }\end{array}$ & 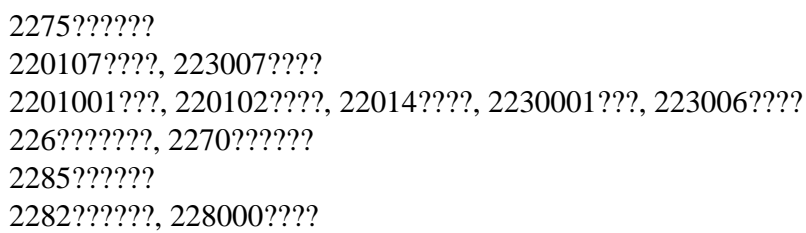 \\
\hline
\end{tabular}

must be used. In the current iteration of the ESP methodology (v1.0), national-scale growth rates for these emissions are generated from industry-specific growth projections that are produced by the US EPA's Economic Model for Environmental Policy Analysis (EMPAX) (RTI International, 2008). Similarly, MARKAL does not include non-combustion emissions from the residential and commercial sectors. Growth factors for these emissions are linked to county-level population projections. While there are alternative sources for such projections, in ESP v1.0 we have used the Integrated Climate and Land Use Scenarios (ICLUS) model (US EPA, 2009c). The resulting economic- and population-based growth factors are matched to SCCs and are inserted into the SMOKE growth and control factor file.

After emission growth factors have been developed, SMOKE grows the base-year inventory using the multiplicative factors within the projection packet. SMOKE disaggregates $\mathrm{NO}_{\mathrm{x}}, \mathrm{PM}$, and VOC emissions into their constituent chemical species using a library of SCC-specific chemical speciation profiles. Then, SMOKE spatially and temporally allocates emissions into a three-dimensional modeling grid using spatial surrogates and SCC-specific temporal allocation profiles. In the spatial allocation process, point source emissions are allocated directly to the grid cell in which each source's coordinates lie. Non-point emission sources are characterized at the county level. SMOKE allocates these emissions to grid cells based on spatial surrogates. For example, residential emissions are allocated to the overlapping grid cells in proportion to the population in each grid cell. The resulting gridded file can be used within an air quality model such as the Community Multiscale Air Quality (CMAQ) model (Byun and Schere, 2006) to simulate regional air quality for the modeled scenario.

\subsection{Important considerations}

Aggregation of SCCs into categories using wildcards and the mapping of MARKAL categories to multiple SCC categories are important components of the ESP methodology. Consider the example of a region that transitions from coal to natural gas as its primary fuel in the electric sector. Without SCC aggregation and mapping, multiplicative growth factors would result in natural gas emissions being increased only at the locations where gas turbines exist in the base-year inventory. In reality, the new turbines may be placed at other locations, including perhaps at the sites of the decommissioned coal plants. Problems also arise when a source category appears in a future year but not in the base year. For example, the base year (2005) emissions from coal integrated gasification combined cycle (IGCC) technologies effectively would be zero. A future-year multiplier applied to a base-year value of zero would be meaningless. New emission sources in the inventory would need to be sited geographically, introducing additional spatial uncertainty. These issues cannot be addressed comprehensively except with the development of an 
algorithm for siting future-year emissions. The formulation and parameterization of such an algorithm would undoubtedly introduce uncertainties itself and is beyond the current scope of our work.

In ESP v1.0, we instead use the simplifying approach of smoothing spatial allocation by mapping MARKAL categories to one or more categories of aggregated SCC codes. In the electric sector, for example, the crosswalk maps MARKAL's electric sector emissions to all electric sector SCCs, including external combustion, internal combustion, and area sources.

The use of aggregations requires that the resulting emission factors be interpreted carefully. These factors are intended to characterize regional trends for each class of sources, but they do not explicitly represent changes at any particular source. From the perspective of modeling several decades into the future, we believe that aggregation is more appropriate than detailed mappings given the large uncertainties in both long-term projections of emission drivers and the relationships between those drivers and emissions.

Another consideration pertains to industrial emissions. MARKAL calculates industrial emissions for each combination of technology category, fuel and industry. For example, emissions are estimated for coal-fired boilers within the paper industry. In contrast, entries within the NEI have not uniformly included industrial specificity. Our ESP methodology thus makes the simplifying assumption that boiler emissions will change at the same rate for all industries. This assumption can be revisited if future versions of the NEI include more universal coverage of industrial specificity.

\section{Application}

A 2005 modeling inventory was selected as the base inventory for this application (US EPA, 2010e). Energy system emission growth factors were generated with a version of the EPA's nine-region MARKAL database, calibrated to AEO06. The ESP methodology (v1.0) was applied to grow the base inventory through 2050 for the two scenarios described below. These scenarios represent only two of a large number of potential futures and are not intended to be predictions or to represent most likely outcomes. Instead, the scenarios demonstrate how technology and policy assumptions may impact emission growth factors and how these factors may differ by sector and region. In future work, we will report a more detailed investigation of the emission impacts for a set of wide-ranging scenarios.

Scenario 1. The first scenario was based on the AEO06 "Business as Usual" case, but was extended from 2030 through 2050. $\mathrm{NO}_{\mathrm{x}}$ and $\mathrm{SO}_{2}$ emissions from electric generating units in MARKAL regions 1, 2, 3, 5 and 6 (Fig. 1) were constrained at the regional level to meet projections from the EPA's regulatory impact assessment of the Clean Air Interstate Rule (US EPA, 2005).
Beyond 2020, electric sector $\mathrm{NO}_{\mathrm{x}}$ and $\mathrm{SO}_{2}$ from these regions were capped at their 2020 levels. For all regions, new coal-fired boilers were assumed to use low$\mathrm{NO}_{\mathrm{x}}$ burners, selective catalytic reduction (SCR), and flue gas desulfurization control technologies. Representations of the 2007 Corporate Average Fleet Efficiency (CAFE) standards for light-duty vehicles and the biofuels requirements of the Energy Independence and Security Act of 2007 (EISA) were included (H.R. 6, 2007). Emission factors for light-duty vehicles were obtained from GREET. Emissions from hybrids and plug-in hybrids were reduced by the average fraction of the operating cycle that the vehicles are under electric power. Heavy-duty vehicle emission factors were also obtained from GREET and include sulfur limits on diesel and on-road heavy-duty engine $\mathrm{NO}_{\mathrm{x}}$ limits (US EPA, 2010b). Industrial sector emission factors were developed from GREET and incorporate predicted impacts of New Source Performance Standards (US EPA, 2010a). Emission factors for aircraft, shipping and rail were held constant over the modeling horizon. We will investigate the impact of regulations on emissions from these sources in future work.

Scenario 2. In this scenario, a representation of a $\mathrm{CO}_{2}$ policy was applied to Scenario 1. In addition, optimistic assumptions were made about the availability and growth potential for carbon capture and sequestration (CCS) and renewable energy technologies. The $\mathrm{CO}_{2}$ policy was modeled as a decreasing trajectory of energy system $\mathrm{CO}_{2}$ emissions, resulting approximately in a $25 \%$ reduction in cumulative $\mathrm{CO}_{2}$ emissions from 2000 through 2050. Annual constraints on $\mathrm{CO}_{2}$ emissions were patterned after the US EPA's analysis of recent proposed climate bills, including the Lieberman-Warner Climate Security Act of 2008 (US EPA, 2008) and the American Clean Energy and Security Act of 2009 (US EPA, 2009a). The details of the bills were not modeled, however, so the simulated policy cannot be regarded as representing any specific legislative proposal. Further, while MARKAL was allowed to select technologies to minimize the net present value of the energy system cost, behavioral responses such as conservation and changes in industrial output were not modeled. Emission trading was not modeled explicitly, but because MARKAL optimizes $\mathrm{CO}_{2}$ reductions under a systemwide cap, the model does capture the cost-minimization behavior associated with trading. Many real-world aspects of trading, such as banking and borrowing of permits and transaction costs, are not considered here. The system-wide $\mathrm{CO}_{2}$ emissions for Scenario 1 and the constrained $\mathrm{CO}_{2}$ trajectory for Scenario 2 are shown in Fig. 2. 


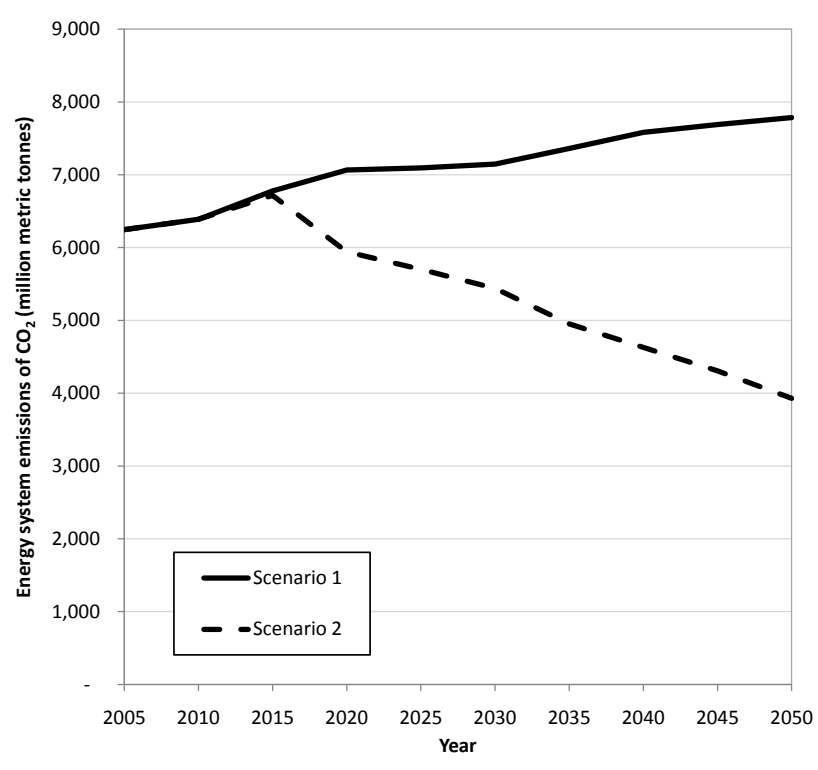

Fig. 2. Annual national emissions of $\mathrm{CO}_{2}$ for Scenarios 1 and 2.

\subsection{Scenario results}

MARKAL was used to optimize technology and fuel selections across all sectors, regions, and time periods for each scenario. Regional outputs are aggregated to the national level to illustrate some of the differences between the two scenarios. For example, Fig. 3 shows electricity production by various technologies. In Scenario 1, pulverized coal combustion holds the largest market share for most of the modeled time horizon. Emission constraints on $\mathrm{NO}_{\mathrm{x}}$ and $\mathrm{SO}_{2}$ limit the growth of coal, however, and its market share decreases. Output from wind, solar and nuclear technologies grows to meet additional electricity needs.

In Scenario 2, existing coal plants are phased out by 2050, being replaced primarily by new IGCC plants with CCS and by additional wind capacity. The $\mathrm{CO}_{2}$ constraints introduce price pressures that result in more efficient end-use technologies, reducing growth in electricity demand between 2015 and 2030. The availability of nearly carbon-free electricity supply after 2030, however, yields major increases in electricity output as other sectors reduce their carbon footprint by converting some portion of fossil fuel demand to electricity.

An example of this transition to electricity use can be seen in Fig. 4, which shows the market share of light-duty vehicle technologies. Through 2030, the distribution of lightduty vehicle technologies is similar between the two scenarios: conventional technologies surrender market share to moderately-improved and advanced internal combustion engines. The scenarios diverge considerably after 2030 as $\mathrm{CO}_{2}$ limits, combined with the availability of a supply of lowcarbon electricity, yield an abrupt transition to plug-in hybrids, electric, and hydrogen fuel cell vehicles. Such a rapid transition would face some barriers not represented explicitly in the model, such as the development of a charging infrastructure. Figure 5 shows trajectories for $\mathrm{CO}_{2}, \mathrm{NO}_{\mathrm{x}}$, and $\mathrm{PM}_{10}$ emissions, normalized to year 2005. $\mathrm{CO}_{2}$ emissions in Scenario 1 increase steadily because of continuing increases in energy demands with only limited drivers for reductions in $\mathrm{CO}_{2}$ intensity. $\mathrm{NO}_{\mathrm{x}}$ and $\mathrm{PM}_{10}$ emissions through 2020 follow a decreasing trend, however, driven by air pollution regulations. While Scenario 2 also experiences increases in energy demands, $\mathrm{CO}_{2}$ emissions decline in response to the $\mathrm{CO}_{2}$ constraints. Emissions of $\mathrm{NO}_{\mathrm{x}}$ and $\mathrm{PM}_{10}$ decline even further in Scenario 2 relative to Scenario 1 because many technologies that are low in $\mathrm{CO}_{2}$ emissions also are low in other pollutant emissions.

\subsection{Calculated emission growth factors}

Regional emission growth factors were developed for Scenarios 1 and 2 using the methodology described in Sect. 2. Tables 2 and 3 include multiplicative growth factors for major energy system categories in Regions 5 and 9, which correspond to the Southeast and Pacific US Census Divisions, respectively. Some of these factors within these tables are similar to the national trends shown in Fig. 2, while others are not, reflecting regional and sectoral differences.

For Region 5 (Table 2), the Scenario 1 results show reductions in $\mathrm{NO}_{\mathrm{x}}$ and $\mathrm{PM}_{10}$ emissions from the electric sector and heavy-duty transportation, signified by growth factors less than 1.0. Light-duty vehicle $\mathrm{NO}_{\mathrm{x}}$ emissions decrease as well. These reductions are due to current emission regulations, the retirement of a small portion of existing coal-fired power plants, and the introduction of new, loweremitting electricity production capacity. Scenario 2 results in additional reductions for many pollutants and sectors. The largest reductions in $\mathrm{CO}_{2}$ emissions in Region 5 are within the electric sector, where emissions are reduced by $96 \%$ from Scenario 1 to Scenario 2. The model achieves this reduction primarily by replacing existing coal-fired power plants with new coal gasification and natural gas facilities, both using CCS. Light-duty transportation also exhibits $\mathrm{CO}_{2}$ emissions reductions from the adoption of plug-in hybrid, fuel cell, and electric vehicle technologies.

For both regions, Scenario 2 tends to result in reductions of pollutant emissions relative to Scenario 1 . There are exceptions in several categories, however. For example, $\mathrm{PM}_{10}$ emissions from the residential sector in Region 5 increase by $12 \%$. This is the result of a small increase in residential wood heating, a major source of residential sector PM.

Region 9 (Table 3) exhibits many of the same overall trends as Region 5. The most notable exceptions, however, are within the electric sector. For Scenario 1, Region 9 growth factors for $\mathrm{NO}_{\mathrm{x}}$ and $\mathrm{PM}_{10}$ are 1.68 and 2.08, respectively. These are considerably greater than corresponding values of 0.35 and 0.61 for Region 5. One reason is that Region 9 starts with a much lower-emitting technology mix 

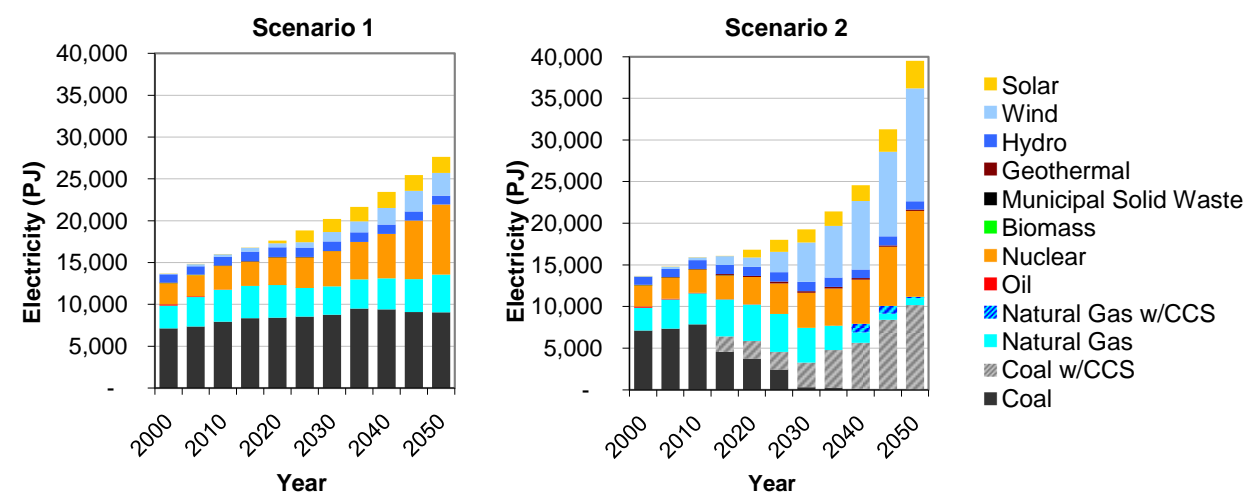

Fig. 3. Production of electricity by technology for Scenarios 1 and 2. Formatted for color reproduction only.
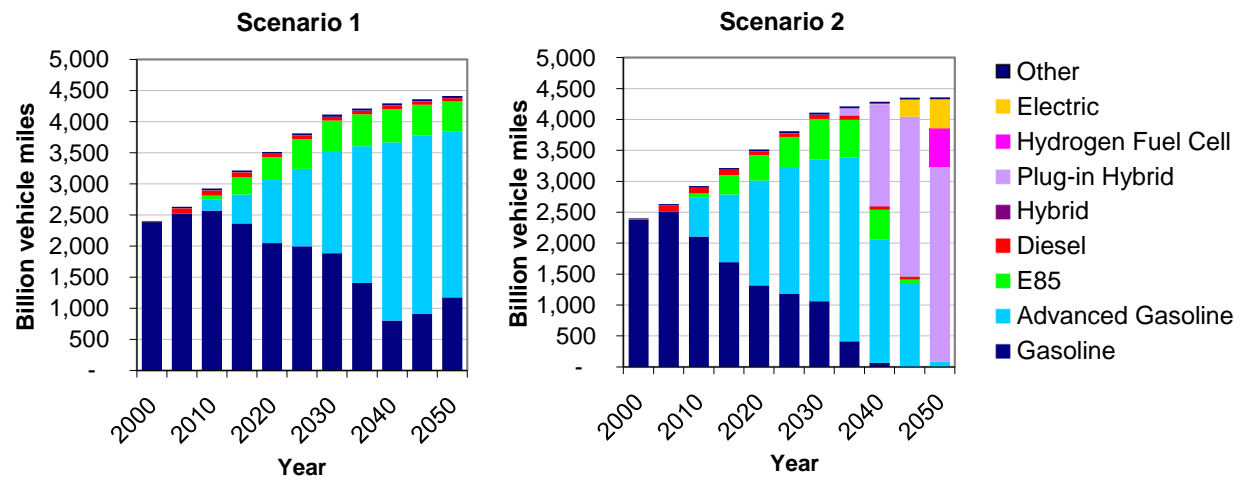

Fig. 4. Market share of light duty vehicle technologies for Scenarios 1 and 2. Formatted for color reproduction only.

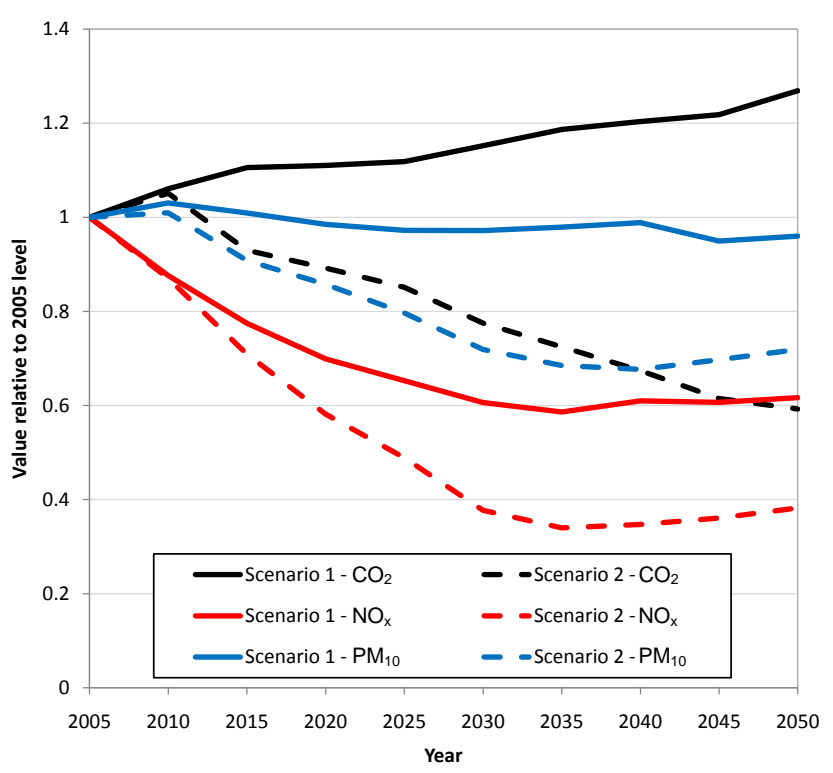

Fig. 5. Changes in national emissions of $\mathrm{CO}_{2}, \mathrm{NO}_{\mathrm{x}}$ and $\mathrm{PM}_{10}$, relative to 2005, for Scenarios 1 and 2. Formatted for color reproduction only. that relies heavily on hydropower. As electricity demand in the region grows, however, the mix shifts toward fossil fuels and pollutant emissions rise. This trend did not occur in $\mathrm{Re}-$ gion 5, where electric sector $\mathrm{NO}_{\mathrm{x}}$ emissions are capped by CAIR.

Growth factors for non-energy sources are shown in Table 4. In this initial application, national-scale factors are used for these sources. This assumption will be revised in subsequent work.

\subsection{Generation and comparison of future-year inventories}

In the previous section, we demonstrated that emission growth factors generated from MARKAL results may differ by scenario, source category, and region. A subsequent step is to use these factors to grow a base-year inventory into the future for each scenario. This step can be carried out in SMOKE. Alternatively, US EPA's Control Strategy Tool (CoST) (US EPA, 2010c) can also be used to develop a future-year inventory based on a SMOKE projection packet. $\mathrm{CoST}$ incorporates many quality assurance features that facilitate analysis of the resulting inventory. 
Table 2. EPA MARKAL Region 5* emissions growth factors, 2005 to 2050, for major energy system emission categories.

\begin{tabular}{|c|c|c|c|c|c|c|c|c|c|}
\hline & \multicolumn{3}{|c|}{ Scenario 1} & \multicolumn{3}{|c|}{ Scenario 2} & \multicolumn{3}{|c|}{ Difference (percent) } \\
\hline & $\mathrm{CO}_{2}$ & $\mathrm{NO}_{\mathrm{x}}$ & $\mathrm{PM}_{10}$ & $\mathrm{CO}_{2}$ & $\mathrm{NO}_{\mathrm{X}}$ & $\mathrm{PM}_{10}$ & $\mathrm{CO}_{2}$ & $\mathrm{NO}_{\mathrm{x}}$ & $\mathrm{PM}_{10}$ \\
\hline Electric sector & 0.91 & 0.35 & 0.61 & 0.04 & 0.24 & 0.41 & -96 & -31 & -33 \\
\hline Industrial combustion & 1.51 & 1.43 & 1.25 & 0.99 & 0.92 & 0.56 & -34 & -36 & -55 \\
\hline Residential combustion & 1.06 & 1.11 & 0.95 & 0.97 & 1.03 & 1.06 & -8 & -7 & 12 \\
\hline Commercial combustion & 1.66 & 1.65 & 1.50 & 1.21 & 1.17 & 0.89 & -27 & -29 & -41 \\
\hline Light duty transportation & 1.44 & 0.24 & 1.94 & 0.71 & 0.11 & 1.64 & -51 & -54 & -15 \\
\hline Heavy duty transportation & 1.62 & 0.06 & 0.11 & 1.57 & 0.06 & 0.11 & -3 & 0 & 0 \\
\hline Airplanes & 1.76 & 1.76 & 1.76 & 1.76 & 1.76 & 1.76 & 0 & 0 & 0 \\
\hline Rail & 1.72 & 1.72 & 1.72 & 1.71 & 1.72 & 1.72 & -1 & 0 & 0 \\
\hline Domestic shipping & 1.35 & 1.35 & 1.35 & 1.35 & 1.35 & 1.35 & 0 & 0 & 0 \\
\hline
\end{tabular}

* Southeast US Census Division; see Fig. 1.

Table 3. EPA MARKAL Region 9* emissions growth factors, 2005 to 2050, for major energy system emission categories.

\begin{tabular}{|c|c|c|c|c|c|c|c|c|c|}
\hline & \multicolumn{3}{|c|}{ Scenario 1} & \multicolumn{3}{|c|}{ Scenario 2} & \multicolumn{3}{|c|}{ Difference (percent) } \\
\hline & $\mathrm{CO}_{2}$ & $\mathrm{NO}_{\mathrm{x}}$ & $\mathrm{PM}_{10}$ & $\mathrm{CO}_{2}$ & $\mathrm{NO}_{\mathrm{x}}$ & $\mathrm{PM}_{10}$ & $\mathrm{CO}_{2}$ & $\mathrm{NO}_{\mathrm{x}}$ & $\mathrm{PM}_{10}$ \\
\hline Electric sector & 1.47 & 1.68 & 2.08 & 0.04 & 0.34 & 0.66 & -97 & -80 & -68 \\
\hline Industrial combustion & 1.41 & 1.45 & 1.35 & 1.08 & 0.99 & 0.68 & -23 & -32 & -50 \\
\hline Residential combustion & 1.13 & 1.13 & 0.89 & 0.81 & 0.84 & 0.96 & -28 & -26 & 8 \\
\hline Commercial combustion & 1.74 & 1.71 & 1.49 & 1.10 & 1.05 & 0.67 & -37 & -39 & -55 \\
\hline Light duty transportation & 1.20 & 0.20 & 1.62 & 0.76 & 0.12 & 1.46 & -37 & -40 & -10 \\
\hline Heavy duty transportation & 1.65 & 0.06 & 0.11 & 1.57 & 0.06 & 0.11 & -5 & 0 & 0 \\
\hline Airplanes & 1.76 & 1.76 & 1.76 & 1.76 & 1.76 & 1.76 & 0 & 0 & 0 \\
\hline Rail & 1.69 & 1.72 & 1.72 & 1.69 & 1.72 & 1.72 & -1 & 0 & 0 \\
\hline Domestic shipping & 1.35 & 1.35 & 1.35 & 1.35 & 1.35 & 1.35 & 0 & 0 & 0 \\
\hline
\end{tabular}

* Pacific US Census Division; see Fig. 1.

If air quality modeling is to be conducted, the steps of speciation and spatial and temporal allocation are performed within SMOKE. We used CoST to construct a 2050 inventory for $\mathrm{NO}_{\mathrm{x}}$ and $\mathrm{PM}_{10}$ emissions in MARKAL Region 5. CoST's quality assurance features were then used to aggregate emissions at the state and sector level. The differences between Scenario 1 and Scenario 2 were calculated, providing an estimate of the annual state-level changes in emissions in 2050 that could result from the application of the hypothetical $\mathrm{CO}_{2}$ policy. These differences are shown in Table 5.

There are some readily apparent differences in trends from one state to another. For example, $\mathrm{PM}_{10}$ emissions decline dramatically under Scenario 2 in Virginia, but increase slightly in North Carolina. These differences reflect the composition of each state's base-year inventory: 2005 emissions from industrial and commercial coal are greater in Virginia by more than a factor of 40 . Coal use in these sectors decreased under Scenario 2, driving the area source reductions seen in Table 5.

\section{Summary and future directions}

We describe version 1.0 of the Emission Scenario Projection (ESP) methodology. The methodology is demonstrated by generating future emission inventories for nine regions within the United States. The methodology focuses on the energy system, allowing alternative future scenarios to be characterized and evaluated. By generating SCC-based emission growth factors, the approach is compatible with existing emission modeling tools, such as SMOKE and CoST. Ultimately, tools and methods such as this are expected to improve the ability of decision-makers to anticipate emission trends, understand how these trends are linked to underlying factors, and identify and evaluate alternative adaptation and mitigation strategies.

The scenarios selected for evaluation in this paper do not represent specific projections or policies. Instead, they illustrate the application of the methodology for a case in which traditional pollutant (i.e., $\mathrm{NO}_{\mathrm{x}}$ and $\mathrm{PM}_{10}$ ) emissions change in response to a GHG policy. The results demonstrate that there can be sectoral, regional, and spatial differences in these reductions. 
Table 4. Non-energy, surrogate-based emission growth factors, 2000 to 2050*.

\begin{tabular}{lll}
\hline Surrogate & Sector Category & Scenarios 1 and 2 \\
\hline & Non-manufacturing industrial sector & 1.13 \\
& Food sector & 1.52 \\
& Primary metals sector & 1.15 \\
& Non-metallic minerals sector & 1.23 \\
Value of shipments & 1.12 \\
& Paper sector & 1.27 \\
& Transportation equipment sector & 0.76 \\
& Chemical sector & 4.04 \\
& Other manufacturing demands & 3.11 \\
& Other industrial sectors & Growth factors vary by county \\
\hline \multirow{3}{*}{ Population } & Commercial sector & in accordance with the ratio of \\
& Residential sector & projected population to 2000 population \\
& Agricultural operations & \\
& and fugitive dust &
\end{tabular}

* Growth factors from MARKAL are for the period 2005 through 2050. In future work we will update the non-energy factors to extend from 2005 to 2050 as well.

Table 5. Differences (Scenario 2 minus Scenario 1) in state- and sector-level emissions of $\mathrm{NO}_{\mathrm{x}}$ and $\mathrm{PM}_{10}$ in the projected 2050 emission inventories (tons per year).

\begin{tabular}{|c|c|c|c|c|c|c|c|c|c|c|}
\hline \multirow[b]{2}{*}{$\begin{array}{l}\text { State } \\
\text { Abbrev. }\end{array}$} & \multicolumn{5}{|c|}{ Differences in $\mathrm{NO}_{\mathrm{x}}$ (tons per year) } & \multicolumn{5}{|c|}{ Differences in $\mathrm{PM}_{10}$ (tons per year) } \\
\hline & $\begin{array}{r}\text { Electric } \\
\text { Utility }\end{array}$ & $\begin{array}{l}\text { Other } \\
\text { Point }\end{array}$ & Area & $\begin{array}{l}\text { Onroad } \\
\text { Mobile }\end{array}$ & $\begin{array}{r}\text { Total } \\
\text { Difference }\end{array}$ & $\begin{array}{r}\text { Electric } \\
\text { Utility }\end{array}$ & $\begin{array}{l}\text { Other } \\
\text { Point }\end{array}$ & Area & $\begin{array}{l}\text { Onroad } \\
\text { Mobile }\end{array}$ & $\begin{array}{r}\text { Total } \\
\text { Difference }\end{array}$ \\
\hline $\mathrm{DE}$ & -1400 & -1900 & -550 & -4 & -3900 & -520 & -880 & 83 & -1 & -1400 \\
\hline FL & -25000 & -7000 & -8200 & -81 & -40000 & -6200 & -7400 & -980 & -21 & -15000 \\
\hline GA & -12000 & -10000 & -12000 & -70 & -34000 & -7200 & -2400 & -4800 & -18 & -14000 \\
\hline MD & -7000 & -3400 & -4900 & -76 & -15000 & -3600 & -1200 & -3000 & -22 & -7800 \\
\hline $\mathrm{NC}$ & -12000 & -11000 & -4000 & -48 & -27000 & -4900 & -3400 & 254 & -13 & -8100 \\
\hline SC & -61000 & -4800 & -5100 & -23 & -71000 & -3900 & -1100 & 113 & -6 & -4900 \\
\hline VA & -7400 & -12000 & -18000 & -63 & -37000 & -2800 & -1700 & -16000 & -18 & -21000 \\
\hline WV & -18000 & -11000 & -4700 & -12 & -34000 & -5900 & -410 & -590 & -3 & -6900 \\
\hline
\end{tabular}

Refinements to the ESP methodology are ongoing. Many of these refinements involve updates to the EPA MARKAL databases. For example, energy resource, technology, and fuel use assumptions are being updated to be consistent with the 2010 version of the US DOE Annual Energy Outlook (US DOE, 2010). Also, pollutant coverage is being expanded to provide system-wide factors for $\mathrm{PM}_{2.5}$, carbon monoxide $(\mathrm{CO})$, methane $\left(\mathrm{CH}_{4}\right)$, nitrous oxide $\left(\mathrm{N}_{2} \mathrm{O}\right)$, VOCs, black carbon, organic carbon, and mercury $(\mathrm{Hg})$. Heavy-duty truck, airplane, train and shipping technology representations are being enhanced to include additional advanced technology options. Planned longer-term improvements to the MARKAL databases include an update to the industrial sector to include greater technological detail and control options, as well as the development of an improved representation of existing coal-fired electric utilities to differentiate those facilities by factors such as age and size.
We plan to investigate a number of additional refinements. For example, we will explore in more detail the implications of SCC aggregation, including comparing the results of different levels of aggregation. We will also examine the advantages and disadvantages of producing industry-specific emission growth rates. In the work presented here, we did not examine how emissions may change seasonally and diurnally in the future. MARKAL can provide insight into temporal allocation of emissions (e.g., from the transition of natural gas from a shoulder-load technology to also meeting base-load electricity demands), and we plan to explore how to make use of this information within SMOKE.

How well MARKAL's base-year inventory compares to the base-year inventory used by SMOKE or CoST is a critical factor in applying multiplicative growth factors. In ongoing work, we are comparing MARKAL's 2005 emission values (produced with a newer version of the nine-region MARKAL database than used in this paper) with the US 
EPA's 2005 National Emission Inventory. This comparison is helping us understand how well MARKAL emission values match the NEI, where emissions coverage should be expanded, and which emission factors in MARKAL should be re-examined. The results of this comparison also will provide guidance and interpretive information to others wishing to use the US EPA MARKAL databases for scenario-based emission projections.

In future work, we will apply the ESP methodology to more widely ranging scenarios that incorporate not only technological and policy assumptions, but also internally consistent assumptions about population, economy, land use, and other factors. Development of a better capability to generate future land cover scenarios will also improve the spatial distribution and resolution when used in conjunction with the methodology presented here.

An advantage of using MARKAL within ESP is its fast runtime, allowing the development of many alternative future scenarios. Emission modeling with SMOKE and air quality modeling with CMAQ have much greater computational time requirements, however, limiting the number of emission scenarios that can be used in air quality simulations. Computational requirements also limit the ability to consider feedbacks, such as the impact of GHG mitigation efforts on radiative forcing and the resulting changes in temperatures and energy demands. The US EPA is developing screening tools that incorporate MARKAL to facilitate the evaluation of the air quality impacts of a larger number of future scenarios, as well as examining the implications of those scenarios for mitigating climate change.

Acknowledgements. The authors would like to acknowledge the contributions of members of the Energy and Climate Assessment Team (ECAT) of the US Environmental Protection Agency's Office of Research and Development. ECAT is responsible for the development and updating of EPA's MARKAL databases. Current team members who have contributed to this work include Cynthia Gage, Tim Johnson, Ozge Kaplan, Carol Lenox, and William Yelverton. We would also like to acknowledge helpful comments by Farhan Akhtar and the reviewers for the Geoscientific Model Development journal.

Disclaimer. This paper has been subjected to the agency's peer and administrative review and has been cleared for publication. The views expressed in this paper are those of the authors and do not necessarily reflect the views or policies of the US Environmental Protection Agency.

Edited by: I. Rutt

\section{References}

Burnham, A., Wang, M., and Wu, Y.: Development and applications of GREET 2.7 -the transportation vehicle cycle model, US Dept. of Energy, Argonne National Laboratory, ANL/ESD/06-5, Argonne, IL, available at: http:/greet.es.anl. gov/publication-lkldbrwj (last access: March 2011), 124 pp., 2006.

Byun, D. W. and Schere, K. L.: Review of the governing equations, computational algorithms, and other components of the Models3 Community Multiscale Air Quality (CMAQ) modeling system, Appl. Mech. Rev., 59, 51-77, 2006.

CMAS: SMOKE Version 2.6 User's Manual. The University of North Carolina, Community Modeling and Analysis System, Chapel Hill, NC, available at: http://www.smoke-model.org/ version2.6/SMOKE_v26_manual.pdf (last access: March 2011), 510 pp., 2009.

Fishbone, L. G. and Abilock, H.: MARKAL: A linearprogramming model for energy-systems analysis: technical description of the BNL version, J. Energy Res., 5, 353-375, 1981.

Houyoux, M. R. and Adelman, Z.: Quality assurance enhancements to the SMOKE modeling system. Tenth Annual Emission Inventory Conference, Denver, CO, 1-3 May, 2001, US EPA, available at: http://www.epa.gov/ttn/chief/conference/ei10/modeling/ houyoux.pdf (last access: March 2011), 12 pp., 2001.

H. R. 6: Energy Independence and Security Act of 2007, US Congress, available at: http://www.gpo.gov/fdsys/search/ pagedetails.action?granuleId=\&packageId=BILLS-110hr6enr (last access: March 2011), 2007.

Loulou, R., Goldstein, G., and Noble, K: Documentation for the MARKAL family of models, available at: http://www.etsap.org (last access: March 2011), 389 pp., 2004.

Nakicenovic, N., Alcamo, J., Davis, G., de Vries, B., Fenhann, J., Gaffin, S., Gregory, K., Grbler, A., Jung, T. Y., Kram, T., La Rovere, E. L., Michaelis, L., Mori, S., Morita, T., Pepper, W., Pitcher, H., Price, L., Riahi, K., Roehrl, A., Rogner, H.-H., Sankovski, A., Schlesinger, M., Shukla, P., Smith, S., Swart, R., van Rooijen, S., Victor, N., and Dadi, Z.: Special report on emission scenarios: A special report of Working Group III of the Intergovernmental Panel on Climate Change, Cambridge University Press, Cambridge, UK, available at: http://www.grida.no/ climate/ipcc/emission/index.htm, (last access: March 2011), 599 pp., 2000.

Nolte, C. G., Gilliland, A. B., Hogrefe, C., and Mickley, L. J.: Linking global to regional models to assess future climate impacts on surface ozone levels in the United States, J. Geophys. Res., 113, D14307, doi:10.1029/2007JD008497, 2008.

Pachauri, R. K. and Reisinger, A. (Eds.): Climate Change 2007: Synthesis report: Contribution of working groups I, II and III to the Fourth Assessment Report of the Intergovernmental Panel on Climate Change, Inter. Panel on Clim. Change, Geneva, Switzerland, 104 pp., 2007.

Peary, M. L., Canziani, O. F., Palutikof, J. P., van der Linden, P. J., and Hanson, C. E. (Eds.).: Climate Change 2007: Impacts, adaptation and vulnerability. Contribution of Working Group II to the Fourth Assessment Report of the International Panel on Climate Change, Cambridge University Press, Cambridge, UK, 976 pp., 2007.

Rafaj, P., Kypreos, S., and Barreto, L.: Flexible carbon mitigation policies: Analysis with a global multi-regional MARKAL 
model, Chapter 9, The Coupling of Climate and Economic Dynamics, edited by: Haurie, A. and Viguier, L., Springer Verlag, New York, 2005.

RTI International: EMPAX-CGE model documentation, Interim report, prepared for the Office of Air Quality Planning and Standards, US EPA, RTI Project Number 0209897.002.041, Research Triangle Park, NC, available at: http://www.epa.gov/ttnecas1/ models/empax_model_documentation.pdf (last access: March 2011), 112 pp., 2008.

Schwartz, P.: The Art of the long view, 2nd Edn., Doubleday, New York, NY, 272 pp., 1996.

US DOE: Annual Energy Outlook 2006 with projections to 2030, US Dept. of Energy, Energy Info. Admin., Office of Integrated Analysis and Forecasting, DOE/EIA-0383(2006), Washington, DC, available at: http://www.eia.gov/oiaf/archive/aeo06/index. html (last access: March 2011), 2006.

US DOE: Annual Energy Outlook 2010 with projections to 2035, US Dept. of Energy, Energy Info. Admin., Office of Integrated Analysis and Forecasting, DOE/EIA-0383(2010), Washington, DC, available at: http://www.eia.gov/oiaf/archive/aeo10/index. html (last access: March 2011), 2010.

US EPA: Compilation of air pollutant emission factors, 5th Edn., US EPA, Office of Air Quality Planning and Standards, Research Triangle Park, NC, available at: http://www.epa.gov/ttn/chief/ ap42/index.html (last access: March 2011), 1995.

US EPA: Clean Air Interstate Rule emissions inventory technical support document, US Environmental Protection Agency, Office of Air Quality Planning and Standards, Research Triangle Park, NC, available at: http://www.epa.gov/cair/pdfs/finaltech01.pdf (last access: March 2011), 2005.

US EPA: MARKAL scenario analysis of technology options for the electric sector: The impact on air quality, US Environmental Protection Agency, Washington, DC, EPA/600/R-06/114, available at: http://www.epa.gov/nrmrl/pubs/600r06114/600r06114. pdf (last access: March 2011), 2006.

US EPA: EPA analysis of the Lieberman-Warner Climate Security Act of 2008: S. 2191 in the 110th Congress, US EPA, 14 March 2008, available at: http://www.epa.gov/climatechange/ economics/economicanalyses.html\#cleanenergy (last access: March 2011), 2008.

US EPA: Assessment of the impacts of global change on regional US air quality: a synthesis of climate change impacts on groundlevel ozone, An interim report of the US EPA Global Change Research Program, National Center for Environmental Assessment, EPA/600/R-07/094F, Washington, DC, available at: http: //www.epa.gov/ncea (last access: March 2011), 2009.

US EPA: EPA analysis of the American Clean Energy and Security Act of 2009, US EPA, 23 June 2009, available at: http://www.epa.gov/climatechange/economics/ economicanalyses.html\#cleanenergy (last access: March 2011), 2009a.

US EPA: Inventory of US greenhouse gas emissions and sinks: 1990-2007, US Environmental Protection Agency, Washington, DC, EPA/430/R-08/005, available at: http://www.epa.gov/ climatechange/emissions/usinventoryreport09.html (last access: March 2011), 2009b.
US EPA: ICLUS v1.2 User's Manual: ArcGis tools and datasets for modeling US housing density growth, US EPA, Office of Research and Development, National Center for Environmental Assessment, Washington, DC, EPA/600/R-09/143A, 2009c.

US EPA: 2005 National Emissions Inventory data \& documentation, US EPA, Washington, DC, available at: http://www.epa. gov/ttn/chief/net/2005inventory.html (last access: March 2011), 2010.

US EPA: Code of Federal Regulations: CFR Title 40 Part 60 Standards of performance for new stationary sources, CFR Title 40 - Protection of the environment, Washington, DC, available at: http://www.epa.gov/lawsregs/search/40cfr.html (last access: March 2011), 2010a.

US EPA: Code of Federal Regulations: CFR Title 40 Part 86 Control of emissions from new and in-use highway vehicles and engines, Title 40 - Protection of the environment, Washington, DC, available at: http://www.epa.gov/lawsregs/search/40cfr.html (last access: March 2011), 2010b.

US EPA: Control Strategy Tool (CoST) development documentation. US Environmental Protection Agency, Washington, DC, available at: http://www.epa.gov/ttnecas1/cost.htm (last access: March 2011), 2010c.

US EPA: Integrated Planning Model (IPM), US EPA, Washington, DC, available at: http://www.epa.gov/airmarkt/progsregs/ epa-ipm/index.html (last access: March 2011), 2010d.

US EPA: Technology Transfer Network Clearinghouse for Inventories and Emission Factors, US Environmental Protection Agency, Washington, DC, available at: http://www.epa.gov/ $\mathrm{ttn} /$ chief/eiinformation.html, Code tables available in the file http://www.epa.gov/ttn/chief/net/neip/appendix_6.mdb (last access: March 2011), 2010e.

Weaver, C. P., Liang, X.-Z., Zhu, J., Adams, P., Amar, P., Avise, J., Caughey, M., Chen, J., Cohen, R. C., Cooter, E., Dawson, J. P., Gilliam, R., Gilliland, A., Goldstein, A. H., Grambsch, A., Grano, D., Guenther, A., Gustafson, W. I., Harley, R. A., He, S., Hemming, B., Hogrefe, C., Huang, H.-C., Hunt, S. W., Jacob, D. J., Kinney, P. L., Kunkel, K., Lamarque, J.-F., Lamb, B., Larkin, N. K., Leung, L. R., Liao, K.-J., Lin, J.-T., Lynn, B. H., Manomaiphiboon, K., Mass, C., McKenzie, D., Mickley, L. J., O’Neill, S. M., Nolte, C., Pandis, S. N., Racherla, P. N., Rosenzweig, C., Russell, A. G., Salath, E., Steiner, A. L., Tagaris, E., Tao, Z., Tonse, S., Wiedinmyer, C., Williams, A., Winner, D. A., Woo, J.-H., Wu, S., and Wuebbles, D. J.: A preliminary synthesis of modeled climate change impacts on US regional ozone concentrations, Bull. Am. Meteor. Soc., 90, 1843-1863, doi:10.1175/2009BAMS2568.1, 2009

Woo, J.-H., He, S., Tagaris, E., Liao, K.-J., Manomaiphiboon, K., Amar, P., and Russell, A. G.: Development of North American emission inventories for air quality modeling under climate change, J. Air Waste Manage. Assoc., 58, 1483-1494, doi:10.3155/1047-3289.58.11.1483, 2008. 